\title{
THE EFFECT OF SOIL ENVIRONMENT ON GERMINATION AND EMERGENCE OF PRICKLY LETTUCE (Lactuca serriola L.)
}

\author{
${ }^{1}$ Jan Kapeluszny, ${ }^{1}$ Małgorzata Haliniarz, ${ }^{2}$ Paweł Harasim \\ ${ }^{1}$ University of Life Sciences in Lublin, Department of Herbology and Plant Cultivation Techniques \\ 20-950 Lublin, Akademicka 13, Poland, e-mail:malgorzata.haliniarz@up.lublin.pl \\ ${ }^{2}$ University of Life Sciences in Lublin, Department of Agricultural and Environmental Chemistry \\ 20-950 Lublin, Akademicka 15, Poland,
}

Received: 10.02.2011

\begin{abstract}
In 2007 mature achenes of prickly lettuce (Lactuca serriola L.) were collected from a winter wheat crop growing on loess-derived brown earth soil, from the side of a dirt road, and from a hybrid alfalfa crop growing on heavy rendzina soil. In March 2008 the germination ability of achenes and the length of roots and above-ground parts of $L$. serriola seedlings were determined. The experiment was set up as a completely randomized design in 6 replicates and it was done in dishes. The dishes were filled with loess-derived brown soil and podzolic soil derived from light loamy sand with different $\mathrm{pH}$ values of 4.5, 5.5 and 7.0 obtained using laboratory methods. The second experiment evaluated the effect of medium type and light conditions on the germination of Lactuca serriola achenes. The experimental design was the same as in the above described experiment.

The study found that there were significantly more germinating seeds from the plants growing in the alfalfa crop and on the dirt roadside compared to the plants from the wheat crop. Emerging plants showed higher germination ability on loess-derived soil with a $\mathrm{pH}$ of 5.5 and 7.0 than on podzolic soil derived from sand with the same $\mathrm{pH}$. Lactuca serriola prefers soils rich in calcium compounds, and developing segetal cenopopulations produce diaspores capable of germination, thereby the numbers of individuals can increase and the continuity of this species in crop fields can be maintained. Seeds germinated significantly better in the dark than under the conditions of 12-hour illumination.
\end{abstract}

Key words: Lactuca serriola, germination, emergence, soil, $\mathrm{pH}$, origin of the mother plant, light conditions

\section{INTRODUCTION}

Among species of the genus Lactuca (f. Asteraceae) found across Poland, prickly lettuce (L. serriola $(\mathrm{L})$.$) has been recorded to date most frequently in$ ruderal habitats (Aniol-Kwiatkowska, 1974; Fijałkowski, 1978; Święs, 1993). This species is now at the initial stage of colonization of segetal communities and the size of its population in weed infestation of crops increases (K a pe lus zny and $\mathrm{Hal}$ in i arz, 2010). In other countries such as, for example: United Kingdom, Czech Republic, Canada, United States of America, this process is already much more advanced (Prince and Carter, 1985; R utledge and McLendon, 2002; Mikulka and Chodova, 2003).

Prickly lettuce, likewise each species, has a unique range of habitat requirements necessary to break the dormancy of seeds and to initiate their germination. The literature of the subject includes the following in the most frequently investigated factors: temperature (Roberts, 1972; Marks and Prince, 1982; Mikulka and Chodova, 2003), type of soil medium (Prince and Carter, 1985), light intensity (Crooker and Barton, 1957; B orthwick et al. 1954; Marks and Prince, 1982). Moreover, the following factors have been proven to have a significant effect on germination: location of seeds in the soil (Mikulka and Chodova, 2003; Lass and Prathe, 2007), origin of the mother plant and time of seeding (seed shedding) (Marks and Prince, 1981; Prince and Carter, 1985) as well as the size of seeds and their location on the plant - larger seeds and those produced on the main stem generally germinate more quickly (R o b e r t s, 1972).

Taking into account existing research, a hypothesis was put forward that under the conditions existing in a cultivated crop, different than those in 
ruderal habitats, diaspores with different physiological properties and varying viability are produced. In order to verify this thesis, the present study investigated germination ability and some traits of emerging plants, depending on soil medium, light conditions, and the origin of the mother plant.

\section{MATERIALS AND METHODS}

Mature achenes of prickly lettuce were collected from a winter wheat (Triticum aestivum L.) crop in August, while in September 2007 from the side of a dirt road and from a crop of hybrid alfalfa (Medicago $x$ varia Mart.). The first two stands were located on deep loess-derived brown soil, on the outskirts of Lublin. The hybrid alfalfa crop, and to be exact, its second regrowth left for seeds, grew on heavy rendzina soil derived from chalk rock, in the village of Pawłów, Municipality of Rejowiec Fabryczny.

Achenes, hereinafter referred to as seeds, were stored in paper bags at room temperature. In March 2008 the seed were subjected to germination. Two types of soil were the medium for germination: loess-derived brown soil and podzolic soil derived from light loamy sand, which were collected from a crop field. The soil media were dried at room temperature and subsequently different $\mathrm{pH}$ values of these soils were obtained using laboratory methods: $4.5,5.5$ and 7.0, respectively. To this end, soil $\mathrm{pH}$ was determined by the potentiometric method in redistilled water. After the initial $\mathrm{pH}$ value was determined, which was 6.73 in brown soil and 5.52 in podzolic soil, the respective amounts of $0.25 ; 0.5 ; 1.0 ; 1.5 ; 2.0 ; 3.0$ and $3.5 \mathrm{ml}$ of $\mathrm{NaOH}$ (at a concentration of $0.1 \mathrm{~mol} \times \mathrm{dm}^{-3}$ ) and $\mathrm{HCl}$ (at a concentration of $0.1 \mathrm{~mol} \times \mathrm{dm}^{-3}$ ) were added to the soil samples. After 24 hours, measurements were made to determine $\mathrm{pH}$ curves. On the same day, based on the charts it was calculated what amounts of base and acid should be added to the soil samples in order to obtain the following soil $\mathrm{pH}$ values: 4.5, 5.5 and 7.0. The $\mathrm{pH}$ values of soil media adopted in the methodology were determined before the establishment of the experiment (Skowron and Skowrońska, 2009). Plastic dishes, $12.0 \mathrm{~cm}$ in diameter and $2.0 \mathrm{~cm}$ high, were filled with soil so prepared. Next, 50 seeds of prickly lettuce were placed on the soil surface in each dish. The experiment was conducted at a temperature of $20-24^{\circ} \mathrm{C}$ and with the moisture content of the medium at a level of $60 \%$ of full water capacity. In order to maintain constant moisture content, the dishes were weighed once per day and evaporated water was replenished. The experiment was set up as a complete randomized design in 6 replicates. After 21 days from seeding, germination ability was determined as well as the length of the above-ground parts and roots of all plants from each dish was measured. The above-ground parts were measured to the tip of the longest leaf.

In addition, in April 2008 we investigated the effect of light and soil medium conditions on germinability of Lactuca serriola achenes. The above described soils with their natural $\mathrm{pH}$ were used in the experiment. 50 seeds, collected the previous year from plants found at a ruderal site, were sown on the medium surface in each dish. One group of dishes was placed in total darkness, while the other one was illuminated for 12 hours (from 7.00 to 19.00) with florescent lamps at an average light intensity of ca. 4000 lux. The experiment was carried out as a completely randomized design in 6 replicates, at room temperature from 20 to $24^{\circ} \mathrm{C}$. The moisture content of the media was maintained at a level of $60 \%$ of full water capacity.

The obtained results of both experiments were statistically analysed using the analysis of variance and comparing the means by Tukey's test at a significance level of $\mathrm{p}=0.05$. Before doing statistical calculations, the percentage values were transformed according to the formula $\mathrm{y}=\arcsin \sqrt{\mathrm{x}}(\mathrm{E}$ l a n d t , 1964).

\section{RESULTS}

Germination ability of prickly lettuce seeds was significantly dependent on the origin of the mother plant, type of soil on which seeds were subjected to germination, and on soil pH. More seeds (by 24\%) germinated on loess-derived soil than on podzolic soil derived from sand. Seeds collected from the alfalfa crop and from the roadside showed significantly higher germinability (by $25 \%$ and $38 \%$, respectively) compared to seeds originating from the wheat crop. The seed trait in question was not proved to be significantly correlated to soil $\mathrm{pH}$ (Table 1). However, soil $\mathrm{pH}$ and soil type were found to have a significant interaction effect on germination. This was evidenced by a significantly higher percentage of germinated seeds on loess soil with a $\mathrm{pH}$ of 5.5 and 7.0 than on podzolic soil with the same $\mathrm{pH}$.

All the studied factors, including soil $\mathrm{pH}$, affected to a lesser or greater degree the morphology of lettuce seedlings, i.e. length of above-ground parts and root length (Tables 2,3). When generalising the results, one should conclude that seedlings that grew on a very acid medium (with a $\mathrm{pH}$ of 4.5 ), podzolic soil, and originated from seeds collected from the winter wheat crop were characterized by the worst parameters. Seeds collected from individuals growing on rendzina soil in the alfalfa crop were characterized by a greater physiological potential that provided a better start for emerging plants compared to seeds originating from the other stands.

In the second experiment, light conditions significantly affected the germination of Lactuca serriola seeds (Table 4). 63.3\% of seeds germinated in 
the dark, whereas in the light only $27.6 \%$. On the other hand, the differences in seed germination on podzolic soil with a $\mathrm{pH}$ of 5.52 and on brown soil with a $\mathrm{pH}$ of
6.73 were not statistically proven. Nevertheless, likewise in the above described experiment, seeds germinated better on brown earth soil.

Table 1.

Germination ability of Lactuca serriola L. seeds depending on soil medium and stand

\begin{tabular}{|c|c|c|c|c|c|}
\hline \multirow{2}{*}{ soil } & \multirow{2}{*}{$\mathrm{pH}$} & \multicolumn{3}{|c|}{ stand } & \multirow{2}{*}{ mean } \\
\hline & & winter wheat & hybrid alfalfa & roadside & \\
\hline \multicolumn{6}{|c|}{ actual data $(\%)$} \\
\hline \multirow{3}{*}{ brown soil } & 4.5 & 38.0 & 72.7 & 70.7 & 60.4 \\
\hline & 5.5 & 59.3 & 65.3 & 78.0 & 67.6 \\
\hline & 7.0 & 62.7 & 77.3 & 94.0 & 78.0 \\
\hline \multicolumn{2}{|c|}{ mean } & 53.3 & 71.8 & 80.9 & 68.7 \\
\hline \multirow{3}{*}{ podzolic soil } & 4.5 & 32.0 & 80.7 & 76.0 & 62.9 \\
\hline & 5.5 & 8.7 & 32.0 & 64.0 & 34.9 \\
\hline & 7.0 & 15.3 & 36.0 & 64.0 & 38.4 \\
\hline \multicolumn{2}{|l|}{ mean } & 18.7 & 49.6 & 68.0 & 45.4 \\
\hline \multicolumn{2}{|c|}{ mean for stands } & 36.0 & 60.7 & 74.4 & \\
\hline \multicolumn{2}{|l|}{$\mathrm{pH}$} & 4.5 & 5.5 & 7.0 & - \\
\hline \multicolumn{2}{|l|}{ mean for $\mathrm{pH}$} & 61.7 & 51.2 & 58.2 & - \\
\hline \multicolumn{6}{|c|}{ transformed data } \\
\hline \multirow{3}{*}{ brown soil } & 4.5 & 0.66 & 1.05 & 1.01 & 0.91 \\
\hline & 5.5 & 0.88 & 0.94 & 1.11 & 0.98 \\
\hline & 7.0 & 0.92 & 1.08 & 1.34 & 1.11 \\
\hline \multirow[t]{2}{*}{ mean } & & 0.82 & 1.02 & 1.15 & 1.00 \\
\hline & 4.5 & 0.58 & 1.14 & 1.07 & 0.93 \\
\hline \multirow[t]{2}{*}{ podzolic soil } & 5.5 & 0.22 & 0.58 & 0.96 & 0.59 \\
\hline & 7.0 & 0.37 & 0.64 & 0.95 & 0.65 \\
\hline \multicolumn{2}{|l|}{ mean } & 0.39 & 0.79 & 0.99 & 0.72 \\
\hline \multicolumn{2}{|l|}{ mean for stands } & 0.61 & 0.91 & 1.07 & - \\
\hline \multicolumn{2}{|l|}{$\mathrm{pH}$} & 4.5 & 5.5 & 7.0 & - \\
\hline \multicolumn{2}{|l|}{ mean for $\mathrm{pH}$} & 0.92 & 0.78 & 0.88 & - \\
\hline \multirow[t]{3}{*}{$\mathrm{LSD}_{(0.05)}$} & & \multicolumn{2}{|c|}{0.12} \\
\hline & & \multicolumn{2}{|c|}{ for stands } & \multicolumn{2}{|c|}{0.18} \\
\hline & \multicolumn{3}{|c|}{$\begin{array}{l}\text { for } \mathrm{pH} \\
\text { for interaction soil } \mathrm{x} \mathrm{pH}\end{array}$} & \multicolumn{2}{|c|}{$\begin{array}{l}\text { n.s. } \\
0.32\end{array}$} \\
\hline
\end{tabular}

Table 2.

Length of above-ground parts (mm) of Lactuca serriola L.

\begin{tabular}{|c|c|c|c|c|c|}
\hline \multirow{2}{*}{ soil } & \multirow{2}{*}{$\mathrm{pH}$} & \multicolumn{3}{|c|}{ stand } & \multirow{2}{*}{ mean } \\
\hline & & winter wheat & hybrid alfalfa & roadside & \\
\hline \multirow{3}{*}{ brown soil } & 4.5 & 22.3 & 23.6 & 20.8 & 22.2 \\
\hline & 5.5 & 26.8 & 28.5 & 26.6 & 27.3 \\
\hline & 7.0 & 29.6 & 36.5 & 37.3 & 34.5 \\
\hline mean & & 26.2 & 29.5 & 28.2 & 28.0 \\
\hline \multirow{3}{*}{ podzolic soil } & 4.5 & 22.3 & 27.3 & 24.4 & 24.7 \\
\hline & 5.5 & 17.4 & 24.9 & 22.1 & 21.4 \\
\hline & 7.0 & 24.7 & 25.4 & 23.7 & 24.6 \\
\hline mean & & 21.5 & 25.9 & 23.4 & 23.6 \\
\hline mean for stands & & 23.9 & 27.7 & 25.8 & - \\
\hline $\mathrm{pH}$ & & 4.5 & 5.5 & 7.0 & - \\
\hline mean for $\mathrm{pH}$ & & 23.4 & 24.4 & 29.5 & - \\
\hline \multirow[t]{4}{*}{$\operatorname{LSD}_{(0.05)}$} & & \multicolumn{2}{|c|}{2.5} \\
\hline & \multicolumn{3}{|c|}{ for stands } & \multicolumn{2}{|c|}{ n.s. } \\
\hline & \multirow{2}{*}{\multicolumn{3}{|c|}{$\begin{array}{l}\text { for } \mathrm{pH} \\
\text { for interaction soil x } \mathrm{pH}\end{array}$}} & \multirow{2}{*}{\multicolumn{2}{|c|}{$\begin{array}{l}3.7 \\
6.5\end{array}$}} \\
\hline & & & & & \\
\hline
\end{tabular}


Table 3.

Root length (mm) in Lactuca serriola $\mathrm{L}$.

\begin{tabular}{|c|c|c|c|c|c|}
\hline \multirow{2}{*}{ soil } & \multirow{2}{*}{$\mathrm{pH}$} & \multicolumn{3}{|c|}{ stand } & \multirow{2}{*}{ mean } \\
\hline & & winter wheat & hybrid alfalfa & roadside & \\
\hline \multirow{3}{*}{ brown soil } & 4.5 & 12.7 & 16.9 & 14.0 & 14.5 \\
\hline & 5.5 & 16.1 & 26.1 & 17.9 & 20.0 \\
\hline & 7.0 & 20.9 & 27.5 & 27.9 & 25.4 \\
\hline \multirow[t]{2}{*}{ mean } & & 16.6 & 23.5 & 19.9 & 20.0 \\
\hline & 4.5 & 10.3 & 18.8 & 17.7 & 15.6 \\
\hline \multirow[t]{2}{*}{ podzolic soil } & 5.5 & 6.9 & 12.5 & 10.7 & 10.0 \\
\hline & 7.0 & 14.8 & 18.7 & 11.7 & 15.1 \\
\hline mean & & 10.7 & 16.7 & 13.4 & 13.6 \\
\hline \multicolumn{2}{|l|}{ mean for stands } & 13.6 & 20.1 & 16.7 & - \\
\hline \multicolumn{2}{|l|}{$\mathrm{pH}$} & 4.5 & 5.5 & 7.0 & - \\
\hline \multicolumn{2}{|l|}{ mean for $\mathrm{pH}$} & 15.1 & 15.0 & 20.3 & - \\
\hline \multirow{4}{*}{$\operatorname{LSD}_{(0.05)}$} & & \multicolumn{2}{|c|}{3.0} \\
\hline & \multicolumn{3}{|l|}{ for stands } & \multicolumn{2}{|c|}{4.4} \\
\hline & \multicolumn{3}{|l|}{ for $\mathrm{pH}$} & \multicolumn{2}{|c|}{4.4} \\
\hline & \multicolumn{3}{|c|}{ for interaction soil x $\mathrm{pH}$} & \multicolumn{2}{|c|}{7.6} \\
\hline
\end{tabular}

Table 4.

Effect of light conditions and soil type on germination of Lactuca serriola L. seeds

\begin{tabular}{|c|c|c|c|c|}
\hline \multirow{2}{*}{ soil } & \multicolumn{4}{|c|}{ light conditions } \\
\hline & light & dark & mear & \\
\hline \multicolumn{5}{|c|}{ actual data (\%) } \\
\hline brown soil & 32.9 & 69.1 & 51.0 & \\
\hline podzolic soil & 22.3 & 57.4 & 39.9 & \\
\hline mean & 27.6 & 63.3 & - & \\
\hline \multicolumn{5}{|c|}{ transformed data } \\
\hline brown soil & 0.59 & 1.10 & 0.85 & \\
\hline podzolic soil & 0.45 & 0.91 & 0.68 & \\
\hline mean & 0.52 & 1.01 & - & \\
\hline \multirow[t]{2}{*}{$\operatorname{LSD}_{(0.05)}$} & $\begin{array}{l}\text { for soils } \\
\text { for light condi }\end{array}$ & & & $\begin{array}{r}\text { n.s. } \\
0.22\end{array}$ \\
\hline & for interaction & itions & & n.s. \\
\hline
\end{tabular}

\section{DISCUSSION}

As reported by Croeker and Barton (1957), the period of seed after-ripening in plants of the genus Lactuca is about 4 months. This applies to dry stored seeds. The present experiment thus fulfilled the basic requirement necessary for evaluation of seed germination ability.

The obtained results prove that a higher $\mathrm{pH}$ of soil, both of that on which the mother plant grew (chalk rendzina) and of the germination medium, had a substantial effect on germinability and the initial growth of seedlings of the species under study. A similar correlation has already been shown in earlier studies of the present authors (Kapeluszny and $\mathrm{Hali}$ $\mathrm{n}$ i a r z , 2011) and of other authors (W e a v e r et al. 2006) with respect to other morphological characters of mother plants and generative reproduction of Lactuca serriola. Numerous older papers (H a r r in g t o n,
1960; Molberg, 1961; Młodzianowska, 1962) as well as more recent ones ( $\mathrm{R} \mathrm{utle} \mathrm{dge} \mathrm{and}$ McLendon, 2002; Halvors on and Guertin, 2003) inform about the stimulating effect of macroelements and humic compounds in the medium on germination and formation of seedlings.

The germination ability of seeds under study was also affected by factors such as the origin of the mother plant as well as the type of medium and its interaction with $\mathrm{pH}$. A similar correlation was demonstrated by Prince and Carter (1985). In our experiment, the percentage of germinating seeds significantly depended on the origin of the mother plant and ranged between $36 \%$ for seeds collected from the winter wheat crop to $74 \%$ for those originating from the roadside; it was also dependent on germination medium (range of variation 45-69\%). One of the reasons for such different germination rates for $L$. serriola seeds is explained by Guter man (1992). This author 
suggests that $L$. serriola has a unique germination mechanism that results in the germination of only a part of mature and shed seeds if there is a high risk of death of seedlings. This is a certain species survival mechanism. Another reason for poorer germination of seeds collected from the winter wheat crop can be sought in their incomplete maturity, to which R o be r t s (1972) draws attention.

In the present study, significantly more seeds germinated in the dark than in the light. Seeds of Lactuca sativa, a species closely related to Lactuca serriola, behave similarly ( $\mathrm{M}$ a y e $\mathrm{r}$ and $\mathrm{Polj}$ ak off- M a y ber, 1963). On the other hand, the study of Rutledge and McLendon (2002) demonstrates that as many as $92 \%$ of seeds germinated both in the light and in the dark. Papers of other authors show a high dependence of the process of $L$. serriola germination on both light conditions and temperature. As reported by Marks and Prince (1982), at a constant temperature of $15^{\circ} \mathrm{C}$ seeds germinated only in the light, whereas under natural changing thermal conditions emergences also occurred in the dark.

\section{CONCLUSIONS}

Prickly lettuce, encroaching into crop fields and colonizing even a dense crop formed by winter wheat, produces diaspores capable of germination. In this way, developing segetal cenopopulations can increase the numbers of this species and ensure the continuity of its occurrence in crops. But segetal individuals differ from those growing on roadsides not only morphologically (Kapeluszny and Haliniarz, 2011), but also in seed quality. Seeds originating from a winter wheat crop germinate and emerge significantly more poorly compared to seeds collected from the side of a dirt road or from an alfalfa crop.

Soil medium onto which seeds fall significantly affects germination and emergence. Emerging plants showed higher germinability on loess-derived soil with a pH of 5.5 and 7.0 than on podzolic soil derived from sand with the same $\mathrm{pH}$. Moreover, the germination of L. serriola $\mathrm{L}$. seeds is dependent on light conditions. In the present experiment, significantly more seeds germinated in the dark than in the light.

\section{REFERENCES}

Anioł-Kwiatkowska J., 1974. Flora i zbiorowiska synantropijne Legnicy, Lubina i Polkowic. / Synanthropic flora and communities of Legnica, Lubin and Polkowice. Acta Univ. Wratisl. 229, Prace Bot. 19: 1-152. (in Polish)

Borthwick H.A., Hendricks S.B., Toole E.H., To ole V.K., 1954. Action of light on lettuce - seed germination. Bot. Gaz. 115: 205-225.
Croeker W., Barton L.V., 1957. Physiology of seeds. Chron. Bot. Co. Waltham.

Elandt R., 1964. Statystyka matematyczna w zastosowaniu do doświadczalnictwa rolniczego. Państwowe Wydawnictwo Naukowe, Warszawa. (in Polish)

Fijałkowski D., 1978. Synantropy roślinne Lubelszczyzny. Państwowe Wydawnictwo Naukowe, Warszawa-Łódź. (in Polish)

Guterman Y., 1992. Maturation dates affecting the germinability of Lactuca serriola L. J. Arid Environ. 22: 352-362.

Halvors on W., Guertin P., 2003. Lactuca serriola L. The University of Arizona, 125, Biological Sciences East, Tucson, Arizona 85721: 1-26.

Harrington J.F., 1960. Germination of seeds from carrot, lettuce and pepper plants grown under severe nutrient deficiencies. Hilgardia, 30 (7): 219-235.

Kapeluszny J., Hal iniarz M., 2010. Niektóre gatunki ruderalne zadomowione $\mathrm{w}$ uprawach na terenie województwa lubelskiego. / Some ruderal species established in crops in the Lublin region. Fragm. Agronom. 27 (2): 70-78. (in Polish)

Kapeluszny J., Haliniarz M., 2011. Zmienność cech morfologicznych oraz plenność sałaty kompasowej Lactuca serriola (L.) w zależności od miejsca występowania. / Variation in morphological characters and seed production capacity of prickly lettuce - Lactuca serriola (L.) depending on its place of occurrence. Ekologia i Technika, 19 (3A): 151-154. (in Polish)

Lass L., Prather T., 2007. Prickly lettuce - Lactuca serriola L. Aquila Vision Inc. www.aquilavision.com. Montana Technology Enterprise Center, Missoula Mt 59802: 40-41.

Marks M., Prince S.D., 1981. Influence of germination date on survival and fecundity in wild lettuce, Lactuca serriola. Oikos, 36 (3): 326-330.

Marks M., Prince S.D., 1982. Seed physiology and seasonal emergence of wild lettuce, Lactuca serriola. Oikos, 38 (2): 242-249.

Mayer A.M., Poljak off-Mayber A., 1963. The germination of seeds. Pergamon Press. Oxford, London, New York, Paris.

Mikulka J., Chodova D., 2003. Germination and emergence of prickly lettuce (Lactuca serriola L.) and its susceptibility to selected herbicides. Plant Soil Environ. 49(2): 89-94.

Młodzianowska D., 1962. Wpływ niektórych substancji nieorganicznych na kiełkujące ziarno i wschody kukurydzy w warunkach niskich temperatur. / The effect of some inorganic substances on germinating maize seeds and maize emergence under low temperature conditions. Hod. Rośl. Aklimat. i Nasien. 6 (3): 257-310. (in Polish)

Molberg E.S., 1961. Injuries effects of fertilizers applied with the seed on the emergence of flax. Canad. J. Sci. 41 (1): 35-43. 
Prince S.D. Carter R.N., 1985. The geographical distribution of prickly lettuce (Lactuca serriola). J. Ecol. 73: 49-64.

Roberts E.H., (ed.), 1972. Viability of seeds. Chapman a. Hall LTD, London.

Rutledge R.C., McLendon T., 2002. An assessment of exotic plant species of Rocky Mountain National Park. Colorado State University. 97pp: http://www. npwrc.usgs.gov.

Skowron P., Skow rońska M., 2009. Dissolved organic carbon concentrations in drainage waters and soils from agricultural ecosystems. Ecol. Chem. Eng. 1/2: 61-69.

Św ięs F., 1993. Expansion of Iva xanthifolia Nutt in the City of Lublin. Ann. UMCS, sect. C, 48 (11): 105-126.

Weaver S., Cluney K., Downs M., Page E., 2006. Prickly lettuce (Lactuca serriola L.) interference and seed production in soybeans and winter wheat. Weed Sci. 54 (3): 496-503.

\section{Wpływ środowiska glebowego na kiełkowanie i wschody sałaty kompasowej (Lactuca serriola L.)}

\section{Streszczenie}

W roku 2007 dojrzałe niełupki sałaty kompasowej - Lactuca serriola L. zebrano z łanu pszenicy ozimej, rosnącej na glebie brunatnej wytworzonej z lessu, z pobocza drogi polnej oraz z łanu lucerny mieszańcowej na ciężkiej rędzinie. W marcu 2008 roku oznaczono zdolność kiełkowania niełupek oraz długość korzonków i części nadziemnych siewek L. serriola. Doświadczenie założono w 6 powtórzeniach w szalkach, w układzie kompletnej randomizacji. Szalki napełniono glebą brunatną wytworzoną z lessu oraz glebą bielicową wytworzoną z piasku gliniastego lekkiego, o zróżnicowanym laboratoryjnie pH na 4,5; 5,5 i 7,0. W drugim eksperymencie oceniano wpływ rodzaju podłoża oraz warunków świetlnych na kiełkowanie niełupek Lactuca serriola. Układ doświadczenia był taki sam, jak w wyżej opisanym eksperymencie.

Stwierdzono istotnie więcej kiełkujących nasion pochodzących $\mathrm{z}$ roślin rosnących $\mathrm{w}$ łanie lucerny i na poboczu drogi polnej, w porównaniu do roślin z łanu pszenicy. Wyższą zdolność kiełkowania i lepszy start wschodzącym roślinom zapewniała gleba wytworzona z lessu o pH 5,5 i 7,0, niż gleba bielicowa wytworzona z piasku o takim samym odczynie. Lactuca serriola preferuje gleby zasobne w związki wapnia, a powstające cenopopulacje segetalne tworzą zdolne do kiełkowania diaspory, dzięki czemu może zwiększać się liczebność osobników i ciągłość gatun$\mathrm{ku}$ na polach uprawnych. Istotnie lepiej kiełkowały nasiona w ciemności, niż w warunkach 12 godzinnego oświetlenia. 